\title{
Editorial: the airborne microbiome - implications for aerosol transmission and infection control - special issue
}

\author{
Julian W. Tang ${ }^{1 *}$ (D) and Yuguo Li ${ }^{2}$
}

\begin{abstract}
Although the title of the Special Issue is 'Airborne Microbiome' the manuscripts received have highlighted a variety of peripheral, yet related aspects of this. The contributions are a mixture of primary research, reviews and commentaries, including: new methods to explore environmental niches where such microbes may grow, their detection and characterisation in the human host, which pathogens are present in the respiratory tract and can be exhaled in human breath to potentially spread via the airborne route, and some strategies for their control. Finally, a historical-to-current overview explores human-microbial interactions, including problems with sampling and detection methods, drug resistance, the role of super-spreaders and issues around research funding.
\end{abstract}

Keywords: Airborne, Aerosol, Transmission, Detection, Exhalation, Breath, Infection, Control

Each time a journal puts out a call for a 'Special Issue' on one theme or another, it is never certain what type of response will be received. There may be little or no response at all, or an over-whelming response from which only a few articles can be selected, or, as in this case, there could be an enthusiastic response with a variety of articles from authors who have interpreted the 'Special Issue' theme in different ways.

Although the title of the Special Issue is 'Airborne Microbiome' the manuscripts received have highlighted a variety of peripheral, yet related aspects of this. The contributions are a mixture of primary research, reviews and commentaries, including: new methods to explore environmental niches where such microbes may grow [1], their detection and characterisation in the human host [2-4], which pathogens are present in the respiratory tract and can be exhaled in human breath to potentially spread via the airborne route [5, 6], and some strategies for their control [7]. Finally, a historical-to-current overview explores humanmicrobial interactions, including problems with sampling and detection methods, drug resistance, the role of superspreaders and issues around research funding [8].

\footnotetext{
* Correspondence: julian.tang@uhl-tr.nhs.uk; jwtang49@hotmail.com ${ }^{1}$ Clinical Microbiology, University Hospitals of Leicester NHS Trust, Infirmary Square, Leicester LE1 5WW, UK

Full list of author information is available at the end of the article
}

However it is specifically defined, the general concepts of the airborne microbiome, and the potential risks it can pose to human health, are now well-established amongst academics and the general public. The greatest fear when encountering any new or re-emerging pathogen is how and when it can be transmitted via the airborne route - yet the precise evidence to support such conclusions can be difficult to obtain and interpret in a definitive manner [9-12]. Such evidence and its interpretations are important as they are required to effectively inform infection control guidance, the most obvious being: what protective equipment is required when managing patients infected with pathogens that are potentially airborne-transmissible? [13-15]

Hence, it is in all our interests to continue performing studies to elucidate more precisely the various routes of transmission for different pathogens so that appropriate interventions can be applied when caring for those infected, to prevent secondary spread of these agents. Therefore, we hope that this Special Issue has raised more questions than answers and will inspire more researchers to explore the airborne microbiome in more detail, both for healthcare-related applications, but also, in a much wider sense, to better understand the world in which we all live - and the organisms with which we share it. 


\section{Acknowledgements}

None

\section{Authors' contributions}

Both authors were Guest Editors for this Special Issue and contributed equally to the Editorial. Both authors read and approved the final manuscript.

\section{Funding}

None

\section{Availability of data and materials}

Not applicable

\section{Ethics approval and consent to participate}

Not applicable

\section{Consent for publication}

Not applicable

\section{Competing interests}

The authors declare that they have no competing interests

\section{Author details}

${ }^{1}$ Clinical Microbiology, University Hospitals of Leicester NHS Trust, Infirmary Square, Leicester LE1 5WW, UK. ²Department of Mechanical Engineering, The University of Hong Kong, Haking Wong Building 7/F, Pokfulam Road,

Pokfulam, Hong Kong SAR, China.

Received: 19 December 2018 Accepted: 23 August 2019

Published online: 29 August 2019

\section{References}

1. Horsley A, Thaler DS. Microwave detection and quantification of water hidden in and on building materials: implications for healthy buildings and microbiome studies. BMC Infect Dis. 2019;19(1):67. https://doi.org/10.1186/ s12879-019-3720-1.

2. Wei Z, Zhang X, Wei C, Yao L, Li Y, Zhang X, Xu H, Jia Y, Guo R, Wu Y, Yang K, Gao X. Diagnostic accuracy of in-house real-time PCR assay for mycobacterium tuberculosis: systematic review and meta-analysis. BMC Infect Dis. 2019;19(1):701.

3. Lemma DA, Belachew F, Wondimagegn G, Klinkenberg E. Missed pulmonary tuberculosis: a cross sectional study in the general medical inpatient wards of a large referral hospital in Ethiopia. BMC Infect Dis. 2019;19(1):60. https:// doi.org/10.1186/s12879-019-3716-x.

4. Eshetie S, van Soolingen D. The respiratory microbiota: new insights into pulmonary tuberculosis. BMC Infect Dis. 2019;19(1):92. https://doi.org/10.11 86/s12879-019-3712-1.

5. Carpagnano GE, Susca A, Scioscia G, Lacedonia D, Cotugno G, Soccio P, et al. A survey of fungal microbiota in airways of healthy volunteer subjects from Puglia(Apulia), Italy. BMC Infect Dis. 2019;19(1):78. https://doi.org/10.11 86/s12879-019-3718-8

6. Tellier R, Li Y, Cowling BJ, Tang JW. Recognition of aerosol transmission of infectious agents: a commentary. BMC Infect Dis. 2019;19(1):101. https://doi. org/10.1186/s12879-019-3707-y.

7. Escombe R, Ticona E, Chávez-Pérez V, Espinoza M, Moore D. Improving natural ventilation in hospital waiting and consulting rooms to reduce nosocomial tuberculosis transmission risk in a low resource setting. BMC Infect Dis. 2019;19(1):88. https://doi.org/10.1186/s12879-019-3717-9.

8. Thaler DS, Head MG, Horsley A. Precision public health to inhibit the contagion of disease and move toward a future in which microbes spread health. BMC Infect Dis. 2019;19(1):120. https://doi.org/10.1186/s12 879-019-3715-y.

9. Kilianski A, Evans NG. Effectively communicating the uncertainties surrounding Ebola virus transmission. PLoS Pathog. 2015;11(10):e1005097.

10. Herfst S, Böhringer M, Karo B, Lawrence $P$, Lewis NS, Mina MJ, et al. Drivers of airborne human-to-human pathogen transmission. Curr Opin Virol. 2017; 22:22-9.

11. Tang JW, Hoyle E, Moran S, Pareek M. Near-patient sampling to assist infection control-a case report and discussion. Int J Environ Res Public Health. 2018;15(2):pii: E238.
12. Zhang N, Tang JW, Li Y. Human behavior during close contact in a graduate student office. Indoor Air. 2019:29:577-90.

13. Gralton J, McLaws ML. Protecting healthcare workers from pandemic influenza: N95 or surgical masks? Crit Care Med. 2010;38(2):657-67.

14. Smith JD, MacDougall CC, Johnstone J, Copes RA, Schwartz B, Garber GE. Effectiveness of $\mathrm{N} 95$ respirators versus surgical masks in protecting health care workers from acute respiratory infection: a systematic review and meta-analysis. CMAJ. 2016;188(8):567-74.

15. Maclntyre CR, Chughtai AA, Rahman B, Peng Y, Zhang Y, Seale $H$, et al. The efficacy of medical masks and respirators against respiratory infection in healthcare workers. Influenza Other Respir Viruses. 2017:11(6):511-7.

\section{Publisher's Note}

Springer Nature remains neutral with regard to jurisdictional claims in published maps and institutional affiliations.
Ready to submit your research? Choose BMC and benefit from:

- fast, convenient online submission

- thorough peer review by experienced researchers in your field

- rapid publication on acceptance

- support for research data, including large and complex data types

- gold Open Access which fosters wider collaboration and increased citations

- maximum visibility for your research: over $100 \mathrm{M}$ website views per year

At BMC, research is always in progress.

Learn more biomedcentral.com/submission 